\section{Yield and Growth Response of Onion to Simulated Storm Damage}

\author{
Michael E. Bartolo \\ Arkansas Valley Research Center, Colorado State University, Rocky Ford, \\ CO 81067
}

\author{
Howard F. Schwartz \\ Department of Plant Pathology and Weed Science, Colorado State University, \\ Fort Collins, CO 80523
}

Frank C. Schweissing

Arkansas Valley Research Center, Colorado State University, Rocky Ford, CO 81067

Additional index words. Allium cepa, hail, Alternaria porri, defoliation, injury, purple blotch

\begin{abstract}
Severe storms with high winds, hail, rain, and blowing soil particles can injure onion (Allium cepa L.) leaf and neck tissues. Our study was conducted to determine the growth response of onions to simulated storm damage during bulb development. The effect of removing $33 \%$ and $67 \%$ of the onion foliage at 14, 28, 42, and 56 days before maturity was examined. In 2 years, $67 \%$ defoliation reduced yields more than $33 \%$ defoliation. At both levels, defoliation had a greater impact on total marketable yield and yield of individual market classes when it occurred near the onset of bulbing. Of the different market classes of onions, the jumbo $(>8.25 \mathrm{~cm}$ in diameter) was most consistently affected by defoliation. A moderate $(33 \%)$ and a severe $(66 \%)$ foliage loss delayed crop maturity, decreased total marketable yield and potential market value, and changed the market class distribution of a sweet Spanish-type onion.
\end{abstract}

Onions grown in Colorado and other production areas often are subjected to a variety of storm-related stresses. Some of the most severe damage occurs as a result of hail and driving rain. Severe storms can cause damage to leaf, neck, and bulb tissues, effectively reducing functional leaf area and predisposing plants to infection by plant pathogens. Compared to other crops, onions have a relatively limited leaf area. Onion leaves not only supply photosynthate for plant growth but also contain the receptor that stimulates bulbing (Kato, 1964). As a result, any reduction of leaf area via storm or other damage may have compounding effects on bulb growth and development.

Defoliation during bulb development altered the total yield and market class distribution of 'Downing Yellow Globe' onions in Indiana (Baker and Wilcox, 1961) and 'Yellow Bermuda' onions in southern Texas (Hawthorn, 1949). In Colorado, current cultivars and cropping practices are quite distinct from those used in the studies noted. Thus, onion response to defoliation under modern production conditions in Colorado may be unique. Thornton et al. (1991) used an ice pellet ma-

Received for publication 2 May 1994. Accepted for publication 4 Aug. 1994. Funding was provided by Colorado Agricultural Expt. Station Projects 744 and 717. We thank Marvin Wallace and Thomas Lopez for their technical support. The cost of publishing this paper was defrayed in part by the payment of page charges. Under postal regulations, this paper therefore must be hereby marked advertisement solely to indicate this fact. and $\$ 220 / t$ for medium- and prepack-class onions. type onions and, more importantly, provide a database for future modeling efforts on onion plant response to environmental and pest stresses.

\section{Materials and Methods}

This study was conducted in field trials at the Arkansas Valley Research Center, Rocky Ford, Colo., on a Rocky Ford silty clay loam [Ustic Torriorthents, fine silty, mixed (calcareous), mesic]. 'Colorado 6' onion seeds (a yellow, long-day, sweet Spanish type) were sown on 9 Mar. 1991 and 13 Mar. 1992 in a double-row bed with $46 \mathrm{~cm}$ between rows, an in-row plant spacing of $7.6 \mathrm{~cm}$, and $112 \mathrm{~cm}$ between irrigation furrows. Pests were controlled using established methods (Schwartz et al., 1990), and the crops were irrigated regularly, according to a scheduling program outlined by Kruse et al. (1987), to prevent moisture stress. The experiments were a randomized complete block with eight and four replications in 1991 and 1992, respectively.

On 15 July 1991 and 1992, 56 days before the anticipated maturity date (9 Sept.), the defoliation treatments were initiated. Onion leaves were cut to a uniform length using a battery-powered hedge trimmer and hand sickle. The amount of leaf area removed was estimated visually and according to the method described by Baker and Wilcox (1961). Leaves in treatments defoliated $33 \%$ and $67 \%$ were trimmed to 40 and $20 \mathrm{~cm}$ long (measured from the top of the bulb), respectively. Defoliation was repeated on other plots at 42,28 , and 14 days before the anticipated maturity date. Maturity, measured as the percentage of tops that had fallen over, was recorded on 9 Sept. The plots were harvested on 18 Sept. 1991 and 15 Sept. 1992. The onions from $2.5 \mathrm{~m}$ of both rows in each plot were harvested, and the tops removed with clippers. The onions then were graded into different market classes based on size (diameter in centimeters): jumbo (>8.25), medium (5.70 to 8.25$)$, and prepack (2.54 to 5.70). Then, bulbs were weighed, and the weight percentage of each market class was determined.

Dollar loss amounts were estimated by subtracting the marketable class yields of on-

Table 1. Effect of defoliation on marketable yield, market class distribution, and potential income of onions in 1991. Defoliation occurred at different intervals before the anticipated maturity date of 9 Sept.

\begin{tabular}{|c|c|c|c|c|c|c|}
\hline \multirow{3}{*}{$\begin{array}{l}\text { Days before } \\
\text { maturity }\end{array}$} & \multirow{3}{*}{$\begin{array}{c}\text { Defoliation } \\
(\%)\end{array}$} & \multicolumn{3}{|c|}{ Marketable wt at grading (\%) } & \multirow{3}{*}{$\begin{array}{c}\text { Marketable } \\
\left(\mathrm{t} \cdot \mathrm{ha}^{-1}\right)\end{array}$} & \multirow{3}{*}{$\begin{array}{r}\text { Dollar } \\
\text { loss/ha' }\end{array}$} \\
\hline & & \multicolumn{3}{|c|}{ Bulb size $^{z}$} & & \\
\hline & & Jumbo & Medium & $\overline{\text { Prepack }}$ & & \\
\hline Control & 0 & $51.7 \mathrm{a}^{\mathrm{x}}$ & $45.6 \mathrm{c}$ & $2.7 \mathrm{~d}$ & $88.6 \mathrm{a}$ & --- \\
\hline \multirow[t]{2}{*}{14} & 33 & $45.3 \mathrm{a}$ & $50.6 \mathrm{c}$ & $4.1 \mathrm{~b}-\mathrm{d}$ & $87.0 \mathrm{ab}$ & 610 \\
\hline & 67 & $49.3 \mathrm{a}$ & $47.3 \mathrm{c}$ & $3.4 \mathrm{~cd}$ & $82.1 \mathrm{bc}$ & 1640 \\
\hline \multirow[t]{2}{*}{28} & 33 & $42.5 \mathrm{a}$ & $53.6 \mathrm{bc}$ & $3.9 \mathrm{~b}-\mathrm{d}$ & $87.2 \mathrm{ab}$ & 660 \\
\hline & 67 & $30.8 \mathrm{~b}$ & $64.8 \mathrm{a}$ & $4.4 \mathrm{~b}-\mathrm{d}$ & $70.3 \mathrm{~d}$ & 4990 \\
\hline \multirow[t]{2}{*}{42} & 33 & $44.7 \mathrm{a}$ & $51.5 \mathrm{c}$ & $3.8 \mathrm{~b}-\mathrm{d}$ & $83.8 \mathrm{a}-\mathrm{c}$ & 1390 \\
\hline & 67 & $23.4 \mathrm{~b}$ & $71.2 \mathrm{a}$ & $5.4 \mathrm{ab}$ & $72.6 \mathrm{~d}$ & 4670 \\
\hline \multirow[t]{2}{*}{56} & 33 & $43.0 \mathrm{a}$ & $52.0 \mathrm{c}$ & $5.0 \mathrm{a}-\mathrm{c}$ & $81.7 \mathrm{c}$ & 1940 \\
\hline & 67 & $31.6 \mathrm{~b}$ & $62.1 \mathrm{ab}$ & $6.3 \mathrm{a}$ & $74.6 \mathrm{~d}$ & 3970 \\
\hline
\end{tabular}

${ }^{2}$ Bulb size (diameter in centimeters): jumbo, >8.25; medium, 5.70 to 8.25; prepack, 2.54 to 5.70.

yollar loss based on difference from the control at an average low price of $\$ 260 / \mathrm{t}$ for jumbo-class onions

'Mean separation within columns by Duncan's multiple range test at $P \leq 0.05$. 
ions from defoliated plots from the yields of the control and then multiplying those figures by a low price of $\$ 260 / t$ for jumbo-class onions and $\$ 220 /$ t for medium- and prepackclass onions.

\section{Results and Discussion}

A $67 \%$ defoliation caused a greater change in the yield of individual market classes and total marketable yield than the $33 \%$ in both years (Tables 1 and 2). The jumbo class of onion was affected most consistently by defoliation. In almost all plots, the proportion of jumbo onions decreased with defoliation. This effect was most prominent when defoliation occurred near or soon after the onset of bulbing. "Bulbing," defined as when the bulb diameter is twice that of the neck (Mondal et al., 1986; Steer, 1980), occurred $\approx 45$ to 50 days before the anticipated maturity date in both years.

In 1991, 67\% defoliation of onion plants at $14,28,42$, and 56 days before maturity caused a $10 \%, 52 \%, 63 \%$, and $51 \%$ reduction, respectively, in jumbo yields compared to the control. A 33\% defoliation at these dates caused a $15 \%, 21 \%, 17 \%$, and $24 \%$ reduction, respectively, in jumbos (Fig. 1, top). Yield of the medium-grade market class was not as affected by defoliation as the yield of the jumbo class. In almost all plots, the percentage of onions in the medium class increased with injury severity (Table 1 ). The medium class provided high yields even when onions were $67 \%$ defoliated 42 or 56 days preharvest.

In $1992,67 \%$ defoliation at $14,28,42$, and 56 days before maturity caused a $7 \%, 61 \%$, $95 \%$, and $91 \%$ reduction, respectively, in jumbo yields compared to the control. A $33 \%$ defoliation on the same dates caused a $9 \%$, $0 \%, 41 \%$, and $53 \%$ reduction, respectively, in the jumbo class (Fig. 1, bottom). Again, total marketable yields were affected less by defoliation than the yield of onions in the jumbo class. The maximum reduction in total marketable yield was $32 \%$ of the control and occurred in the $67 \%$ defoliation treatment at 42 days before maturity (Table 2). As in 1991, the percentage of onions in the medium class increased with defoliation.

In addition to the effect on yield, defoliation influenced plant maturity. In 1991, defoliation delayed the lodging of onion tops. Mostly, lodging was delayed more in the 67\% rather than $33 \%$ defoliation treatment (Table 3 ). The delay in lodging of the tops may be attributed partly to the fact that the tops of defoliated onions had less leaf area and, thus, weighed less than the control. However, the treatments defoliated 56 days (33\% and $67 \%$ ) and 42 days $(33 \%)$ before maturity had regrown a full complement of leaves, and their canopies were visually indistinguishable from controls at the time the maturity ratings were taken.

In 1992, this delayed maturity was not evident, probably because foliar disease, such as purple blotch caused by Alternaria porri (Ellis) Cif., equally hastened the lodging of tops in all treatments.
Table 2. Effect of defoliation on marketable yield, market class distribution, and potential income of onions in 1992. Defoliation occurred at different intervals before the anticipated maturity date of 9 Sept.

\begin{tabular}{|c|c|c|c|c|c|c|}
\hline \multirow{3}{*}{$\begin{array}{l}\text { Days before } \\
\text { maturity }\end{array}$} & \multirow{3}{*}{$\begin{array}{c}\text { Defoliation } \\
(\%)\end{array}$} & \multicolumn{3}{|c|}{ Marketable wt at grading (\%) } & \multirow{3}{*}{$\begin{array}{c}\text { Marketable } \\
\left(\mathrm{t} \cdot \mathrm{ha}^{-1}\right)\end{array}$} & \multirow{3}{*}{$\begin{array}{r}\text { Dollar } \\
\text { loss/hay }\end{array}$} \\
\hline & & \multicolumn{3}{|c|}{ Bulb size $^{2}$} & & \\
\hline & & Jumbo & Medium & Prepack & & \\
\hline Control & 0 & $32.0 \mathrm{ab}^{\mathrm{x}}$ & $65.4 \mathrm{~b}$ & $2.6 \mathrm{~b}$ & $88.9 \mathrm{a}$ & --- \\
\hline \multirow[t]{2}{*}{14} & 33 & $29.9 \mathrm{ab}$ & $66.2 \mathrm{~b}$ & $3.9 \mathrm{~b}$ & $87.3 \mathrm{ab}$ & 450 \\
\hline & 67 & $30.3 \mathrm{ab}$ & $66.6 \mathrm{~b}$ & $3.1 \mathrm{~b}$ & $86.9 \mathrm{ab}$ & 520 \\
\hline \multirow[t]{2}{*}{28} & 33 & $32.7 \mathrm{a}$ & $63.9 \mathrm{~b}$ & $3.4 \mathrm{~b}$ & $84.8 \mathrm{ab}$ & 930 \\
\hline & 67 & $14.7 \mathrm{bc}$ & $82.2 \mathrm{a}$ & $3.1 \mathrm{~b}$ & $74.6 \mathrm{c}$ & 3840 \\
\hline \multirow[t]{2}{*}{42} & 33 & $21.3 \mathrm{ab}$ & $74.8 \mathrm{ab}$ & $3.9 \mathrm{~b}$ & $78.4 \mathrm{bc}$ & 2780 \\
\hline & 67 & $2.8 \mathrm{c}$ & $90.1 \mathrm{a}$ & $7.1 \mathrm{ab}$ & $60.8 \mathrm{~d}$ & 7250 \\
\hline \multirow[t]{2}{*}{56} & 33 & $15.9 \mathrm{a}-\mathrm{c}$ & $78.9 \mathrm{ab}$ & $5.2 \mathrm{~b}$ & $81.6 \mathrm{a}-\mathrm{c}$ & 2220 \\
\hline & 67 & $3.9 \mathrm{c}$ & $85.2 \mathrm{a}$ & $10.9 \mathrm{a}$ & $63.2 \mathrm{~d}$ & 6690 \\
\hline
\end{tabular}

${ }^{2}$ Bulb size (diameter in centimeters): jumbo, $>8.25$; medium, 5.70 to 8.25 ; prepack, 2.54 to 5.70 .

yollar loss based on difference from the control at an average low price of $\$ 260 / t$ for jumbo-class onions and $\$ 220 / t$ for medium- and prepack-class onions.

${ }^{x}$ Mean separation within columns by Duncan's multiple range test at $P \leq 0.05$.
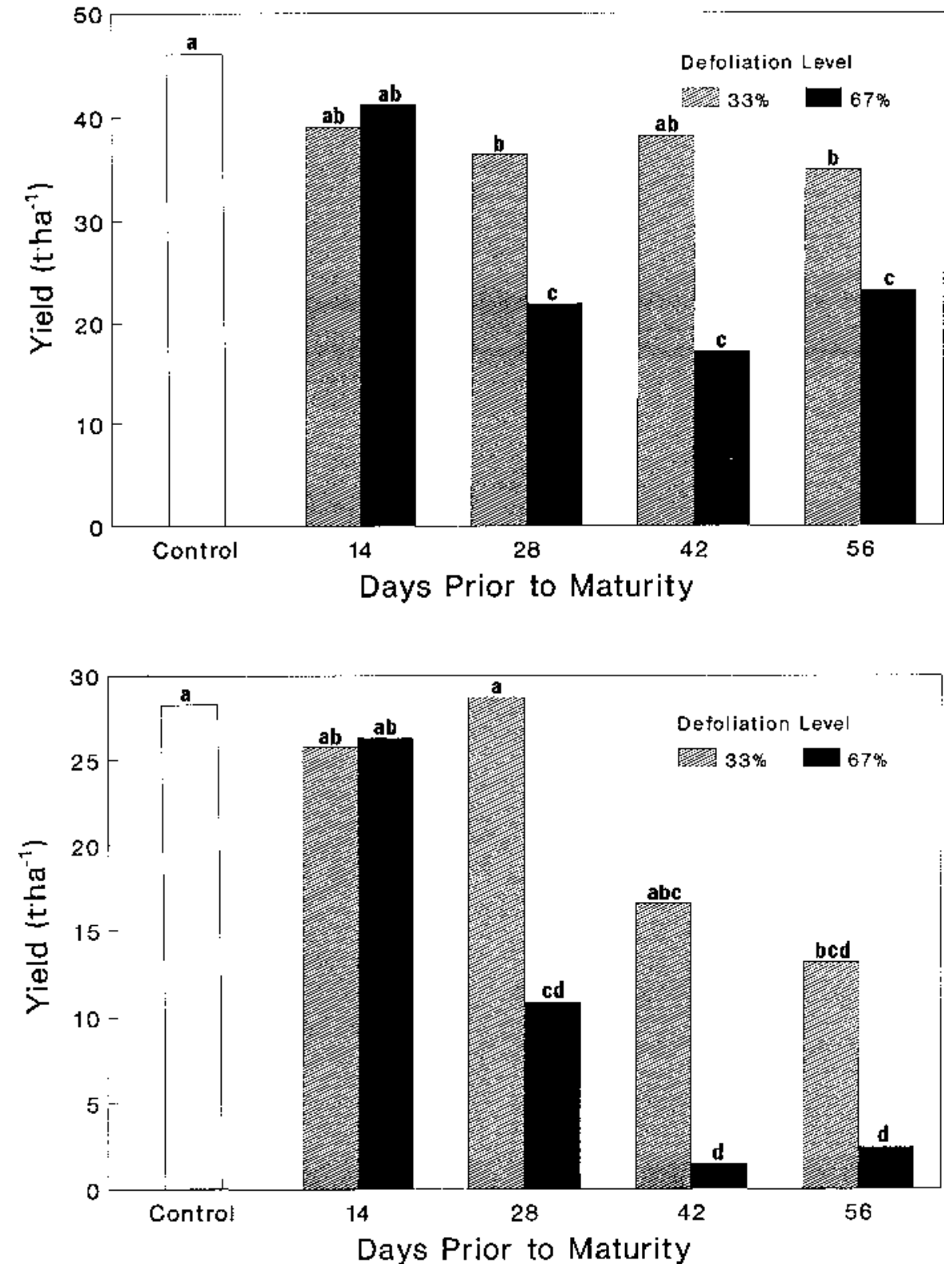

Fig. 1. Effect of defoliation on the yield of onions in the jumbo class ( $>8.25 \mathrm{~cm}$ in diameter) in (top) 1991 and (bottom) 1992. Defoliation occurred at different intervals before the anticipated maturity date of 9 Sept. in both years. Bars with the same letter are not significantly different according to Duncan's multiple range test at $P \leq 0.05$. 
Table 3. Effect of defoliation at various times on onion maturity as measured by percentage of tops lodged. Readings were taken 9 Sept. 1991.

\begin{tabular}{lcc}
\hline $\begin{array}{l}\text { Days before } \\
\text { maturity }\end{array}$ & $\begin{array}{c}\text { Defoliation } \\
(\%)\end{array}$ & $\begin{array}{c}\text { Tops down } \\
(\%)\end{array}$ \\
\hline Control & 0 & $71.2 \mathrm{a}^{\mathrm{z}}$ \\
14 & 33 & $40.0 \mathrm{~b}-\mathrm{d}$ \\
& 67 & $30.0 \mathrm{c}-\mathrm{e}$ \\
28 & 33 & $42.5 \mathrm{bc}$ \\
& 67 & $3.5 \mathrm{f}$ \\
42 & 33 & $52.5 \mathrm{~b}$ \\
& 67 & $13.7 \mathrm{ef}$ \\
56 & 33 & $40.0 \mathrm{~b}-\mathrm{d}$ \\
& 67 & $22.5 \mathrm{de}$
\end{tabular}

${ }^{2}$ Mean separation within columns by Duncan's multiple range test at $P \leq 0.05$.

The total marketable yields for most treatments were similar in both years of the study (Tables 1 and 2). However, the percentage of jumbo onions was consistently lower in 1992 than in 1991. The disparity in jumbo class yields between the 2 years may be related partly to the disease infestation during 1992. In 1991, there was relatively little disease pressure. In 1992, disease pressure was high, and fungicides were applied regularly as dictated by disease incidence in the plots and surrounding border crop. Despite the fungicide applications, all treatments were infected to some extent. Although the infection level was not assessed quantitatively, disease appeared to be more intense on defoliated treatments.

Everts and Lacy (1990) and Miller (1983) indicated that purple blotch development is associated with leaf senescence and late- season growth of new foliage, such as that which developed after damage in our studies. As a result, disease infestation may have accentuated yield losses in damaged plants by further reducing functional leaf area. This observation illustrates some of the secondary effects of foliar damage and the need for careful management soon after storm or other damage occurs. Disease infestation stimulated by defoliation may have additional effects on crop productivity by decreasing bulb quality during storage. Although this aspect of foliar damage was not examined in this study, it may be a valuable characteristic to examine in future projects.

Our findings are consistent with those of Thornton et al. (1991). Defoliation had the greatest impact on total marketable yield and yield of individual market classes when it occurred near the onset of bulbing. Of the different onion market classes, the percentage of onions in the jumbo class decreased and the percentage in smaller grades increased with defoliation. Although total marketable yields were not as dramatically affected as jumboclass yields, losses due to defoliation are nonetheless significant because the larger marketclass onions (i.e., jumbos) typically command a higher price than smaller class onions. Potential onion market value was reduced by $\$ 450$ to $\$ 2780 /$ ha and $\$ 520$ to $\$ 7250 /$ ha for $33 \%$ and $67 \%$ defoliation, respectively (Tables 1 and 2). In addition to the effects on yield, defoliation can delay crop maturity, and if suitable environmental conditions exist, may predispose the plants to disease infection.

\section{Literature Cited}

Baker, R.S. and G.E. Wilcox. 1961. Effect of foliage damage and stand reduction on onion yield. Proc. Amer. Soc. Hort. Sci. 78:401-405.

Everts, K.L. and M.L. Lacy. 1990. The influence of dew duration, relative humidity, and leaf senescence on conidial formation and infection of onion by Alternaria porri. Phytopathology 80:1203-1207.

Hawthorn, L.E. 1949. Simulated hail injury on yellow Bermuda onions. Proc. Amer. Soc. Hort. Sci. 43:265-271.

Kato, T. 1964. Physiological studies on bulb formation and dormancy in the onion plant. III. Effects of external factors on bulb formation and development. J. Hort. Assn. Jpn. 31:53-57.

Kruse, G.E., J.E. Ells, and A.E. McSay. 1987. Comparison of two onion irrigation scheduling programs. J. Amer. Soc. Hort. Sci. 112:738742.

Miller, M.E. 1983. Relationship between onion leaf age and susceptibility to Alternaria porri. Plant Dis. 67:284-286.

Mondal, M.F., J.L. Brewster, G.E.L. Morris, and H.A. Butler. 1986. Bulb development in onion (Allium cepa L.). I. Effects of plant density and sowing date in field conditions. Ann. Bot. 58:187-192.

Schwartz, H.F., P. Westra, and W. Cranshaw. 1990. Colorado onion IPM bulletin. Colorado State Univ. Coop. Ext. Bul. 547A.

Steer, B.T. 1980. The bulbing response to daylength and temperature of some Australasian cultivars of onion (Allium cepa L.). Austral. J. Agr. Res. 31:511-514.

Thornton, M., J. Torell, C. Shock, T. Steiber, and M. Saunders. 1991. Estimating losses due to hail damage in onions, p. 77-87. Proc. Natl. Onion Res. Conf., Savannah. 